ば，伹液中のへモグロビンにどれだけ酸素が結合 しているかを知ることができる。

\section{2. どのように吸光特性を測るか}

採血した俰液の場合には，一定の厚みのセルに 渾たした血液に光を照射したときの透過光强度か らIIII液の吸光特性を知ることが可能である．任液 の吸光特性が分かれば，酸素飽和度を求めること ができる

ところが採l林せずに体の外から血液の色を知万 うとすると，拍液以外の組織を介することにな る。また，動脈血と静脈血が存在するなかからど ちらか一方の情報を取り出す必要もある。さらに 测定対象となる血液の厚みも一定ではない。パル スオキシメータでは, 複数の波長の光電脈波を用 いることにより，動脈血のみの吸光特性を取り出 すことを可能にしている。

\section{3. 光電脈波とは何か}

指などの比較的薄い組織に光をあてて，透過光 強度を測定すると図 2 のような波形が得られる。 このなかの波打っている部分は，心臟の拍動によ る動脈内の血液量の変化によるものである。心蔵 の収縮により!III液が送り出されると、和管内の血液 が増大し，透過光強度は弱くなる。断に心蔵が抎 赈している間は，血管内の血液量が減少するた め，透過光強度は溞くなる，透過光強度が分かれ ば光がどの程度吸収されたかが分かる，光の吸収 の程度を吸光度という。透過光強度と光吸収の時 間的変化は図 2c0ような波形になる。この波形 の波打っている部分を光䉓脈波という.

\section{4. 光電脈波の振幅から何が分かるか}

光電脈波の振幅は，脈拍によって生じる血液量 変化のほかに，照射した光の波長によっても大き さが変わる．これは光の波長と血液の吸光特性の 間に図 1 で示したような関倸があるからである。 また，血液の吸光特性は陵素飽和度によっても変 化する，脈拍による和液の変化量が同じであって も，その!血液の酸素飽和度によって得られる光電

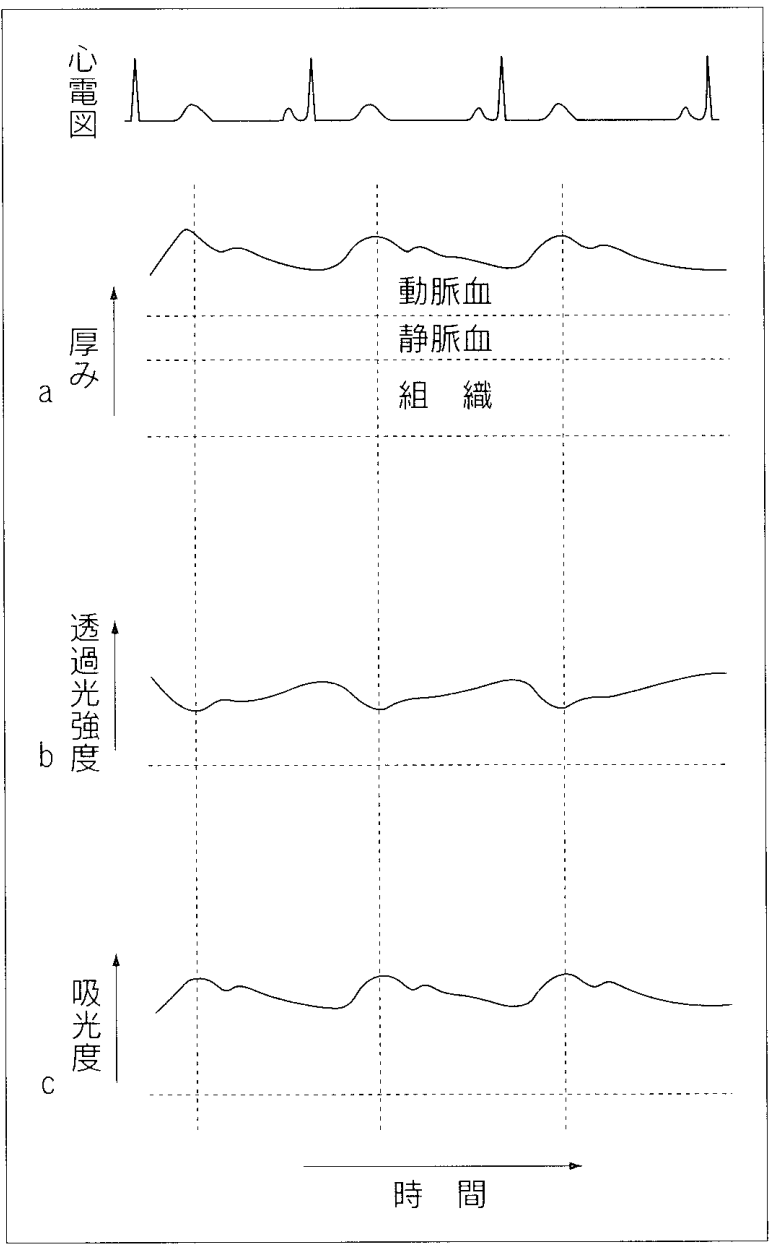

図 2 血液量の変動と光電脈波

脈波の振幅は異なったものになる。

このことを図 3 によって説明する。照射する光 を660 nm と940 nmであるとする。全へモグロ ビンが酸化へモグロビンである場合，酸素飽和度 は100\%であり，2つの波長の光によって得られ る光電脈波の関係は，図3aに示すようになる。 同様に全へモグロビンが還元へモグロビンである 場合は酸素飽和度が $0 \%$ であり，光電脈波の振幅 は図 3bで示すようになる。

このように $2 つ の$ 波長の光によって得られる 光電脈波の振幅比は，脈打っている血液の酸素飽 和度によって決まる。言い挨えれば，2つの波長 の光による光電脈波の振幅比が求められれば，動 脈血酸素飽和度を求めることができる。 
図 3 光の波長と脈波振幅の関係 a：酸素館和度 $100 \%$ の場合 $\mathrm{b}$ : 酸素能和度 $0 \%$ の場合

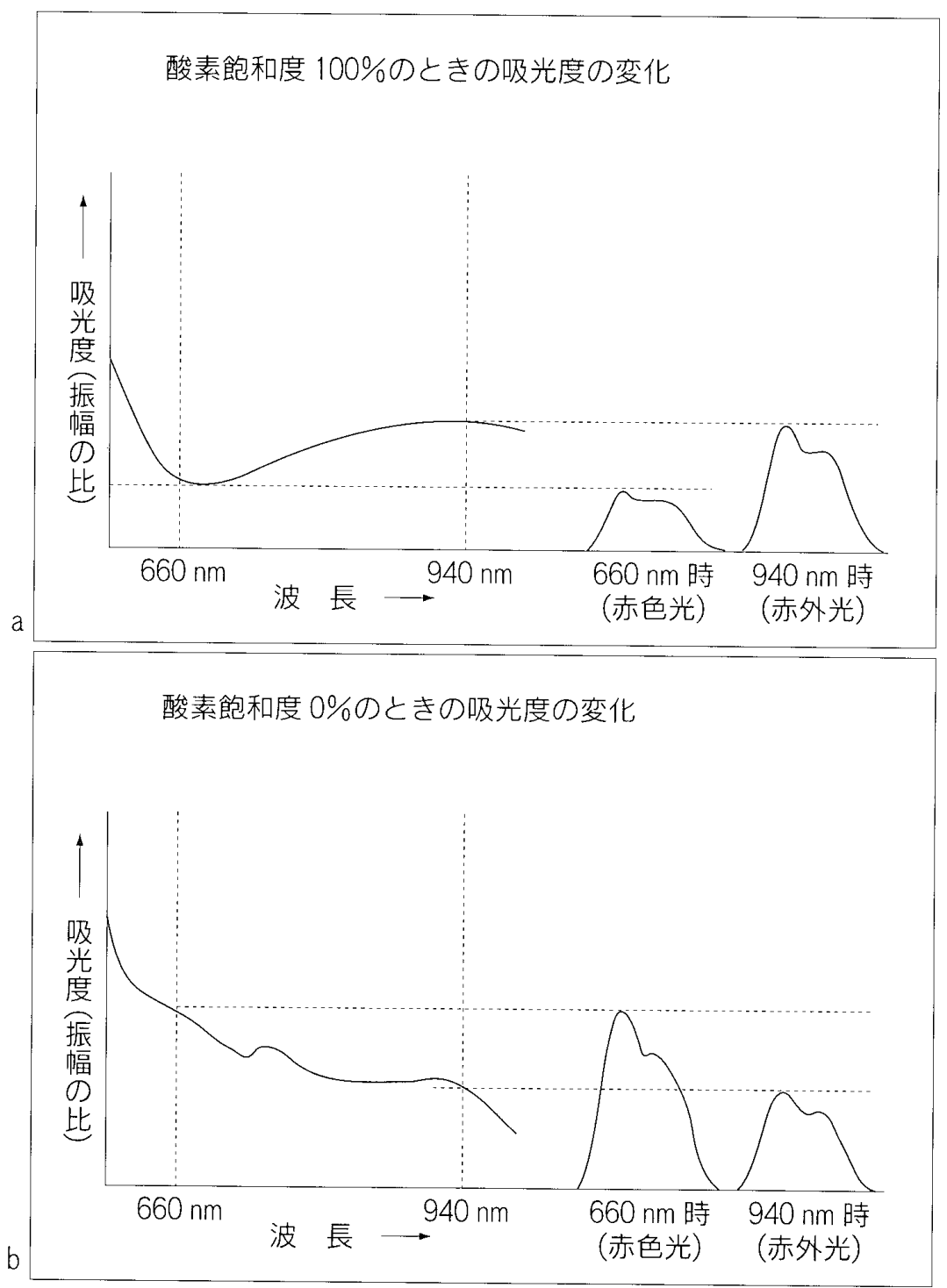

ty

\section{パルスオキシメータの構造}

パルスオキシメータは体に装着するプローブと 本体によって構成される，図４に示すブロック図 により動作の流れを簡単に説明する。

プローブには発光部と受光部があり，その間に 指などの測定部位が挟まれる構造になっている。 発光部には電流を光に変換するLED という素子 が用いられる。波長は660 nm と $940 \mathrm{~nm}$ が用い られることが多い，2つの LED は交互に発光す る。

受光部には光を電流に変換するフォトダイオー ドという素子が用いられる。透過光はフォトダイ
オードによって電流に変換される。さらに電压に 変換され，それぞれの波長の透過光强度信号に分 離される。

透過光強度信号から吸光度の脈波成分を取り壮 し, 振幅の比を算出し, 酸素飽和度に換算する.

\section{パルスオキシメータの誕生}

パルスオキシメータが㗓生するまでの，酸絜测 定の歴史は以下の通りである1,2).

1897年 Danneelによる白金電極を用いた 酸素分王測定法の発見

1904年 Bohr による酸素解離曲線の発見 


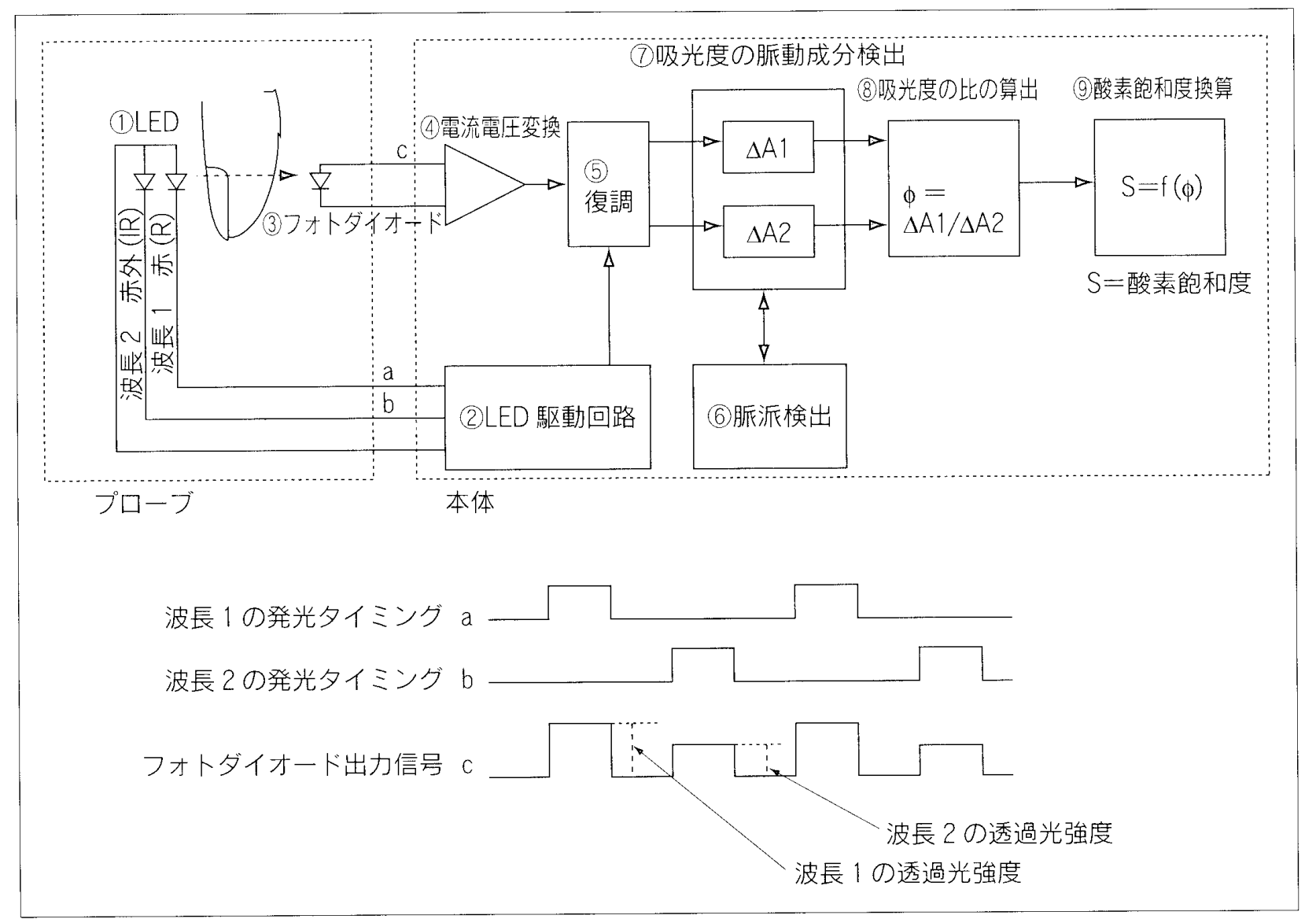

図4 パルスオキシメータの構造（ブロック図）

1932年 Nicolai によるへモグロビン分光光 度测定の発明

1933年 Millikanによるイヤオキシメータ の発明

1949年. Woodによる虚舀操作を用いたイ ヤオキシメータの改良

1953年 Clarkによる酸素分生測定白金電極 の改良

1969年 Huch による経皮酸素分压測定器の 開発

1974年 青柳によるパルスオキシメータの 発明

パルスオキシメータの原理は青柳によって1974 年に初めて発裴された。本人の談によれば，その 着想を得たのは1972年の末，きっかけは次の通 りである。

当時の青柳の研究テーマは色素希釉曲線の新し
い測定法であった。血液中に注入した色素の濃度 变化を無侵襲測定する方法としては，すでに耳梁 の透過光を用いるものがあった。しかしそれは测 定精度の恶いものであった。これを放善するた法 として，青柳が参考にしたのは，かつてオキシ メータにおいて Millikanの抾を改善するため にWoodが採った方法であったＷoodの方法 とは，耳架を压迫して虚晌状態にしたときの透過 光强度と，压迫を解除してlíl液が戻ったときの透 過光強度测定し，前者と後者の美加ら血液による 光吸収を知るというものである，青柳はこの方法 を用いて，血液中の臽素濃度测定を試みていた。

この方法によって得られる透過光強度には脈動

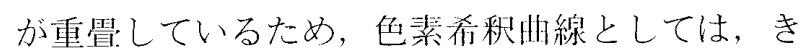
たないものになる。それに気づいた時点で青柳は 強い危惧の念にとらわれた。しかし2つの異な る波長の波形同土の割り算を行うと, 脈波が消え 
てきれいな希釈曲線が得られた。青柳はこのこと を数式で予測したが，実際にそれを目で確かめた ときに確信したのが，“脈波の振幅は虚血操作を して求めた血液の光吸收と同じ情報を持ってい る”ということである。つまり虚血操作をせず に，自然の脈動を用いて血液の吸光特性を測定で きるということである。これがパルスオキシメー タの着想の経緯である ${ }^{3)}$.

\section{パルスオキシメータ使用上の注意点}

\section{1. 異常ヘモグロビン}

ヘモグロビンには，酸化へモグロビンと還元へ モグロビンのほかに，異常へモグロビンと呼ばれ る一酸化炭素へモグロビン $(\mathrm{COHb})$ とメトへモ グロビン（MetHb）がある。COHb蜼素の替 わりに一酸化炭素と結合したへモグロビンであ る、一酸化炭素とへモグロビンの結合は，酸素と ヘモグロビンの結合力より250倍強い。そのため $\mathrm{COHb}$ は酸素連搬の能力を失っている。 MetHb はへモグロビンの $\mathrm{Fe}^{2+}$ が $\mathrm{Fe}^{3+}$ に置き挨わった ものである.MetHb も酸素と結合することがで きない。

酸素飽和度の裴現の方法には，以下の 2 通り がある：

(1)酸化へモグロビンと還元へモグロビンの和を 分母とした場合の酸化へモグロビンの比率

(2)暴常へモグロビンも含めた全へモグロビンを 分母としたときの酸化へモグロビンの比率

(1)は functional $\mathrm{SO}_{2}$, (2) は fractional $\mathrm{SO}_{2}$ と呼 ばれる。

酸素解離曲線で酸素分压との関係が論じられる 酸素飽和度は，(1)の functional $\mathrm{SO}_{2}$ である，巽常 ヘモグロビンには酸素と結合する性質がないから である，一酸化炭素中毒など，買常へモグロビン が問題になる場合は，(2)の fractional $\mathrm{SO}_{2}$ が用い られる。

パルスオキシメータでは 2 波脣で測定してい るために，異常へモグロビンの識別ができない。 パルスオキシメータの測定値は functional $\mathrm{SO}_{2}$ を

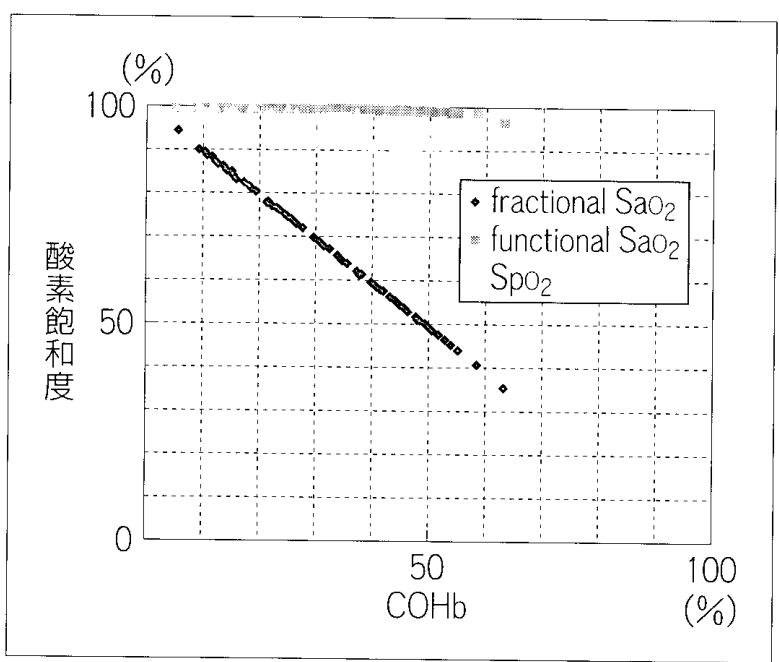

図 $5 \quad \mathrm{COHb}$ と酸素飽和度の関係

基準としているが，異常へモグロビンが增加した 場合には，無視できない誤差を生じる。

成犬 6 頭を用い，100\%酸素濃度の吸気に微䭪! の一酸化炭素を混入させ, $\mathrm{COHb}$ を增大させた ときの，酸素飽和度の变化を図 5 に示す。 $\mathrm{SpO}_{2}$ は functional $\mathrm{SO}_{2}$ でも fractional $\mathrm{SO}_{2}$ でもない值 を示すことが分かる。過去にも同様の報告があ $ろ^{4)}$.

通常 $\mathrm{COHb}$ は $1 \%$ 程度であり，喫煙者であっ ても5\%程度である。その籁网であれば， $\mathrm{SpO}_{2}$ に与える影響は小さい。しかし，一酸化炭素中毒 やメトへモグロビン血症の揚合など，異常へモグ ロビンが増大する場合は，注意が必要である5

\section{2. 体 動}

パルスオキシメータは，透過光の変動が测定部 位の動脈血增減に由来することが前提である。测 定中の体動は，動脈血以外の要因による透過光变 動が生じる．動脈血以外の変動要因としては，静 脈血之組織の厚みが考えられる。

静脈向血の変動を脈拍と䛊認識した場合は, $\mathrm{SpO}_{2}$ は静脈血酸素飽和度に近づく。

組織の厚みの变動を脈拍と愦認識した場合は, 赤色と赤外光の変化の比率が約 1 となる。この 場合, $\mathrm{SpO}_{2}$ は約 $85 \%$ を示す。 
いずれの場合も，体動により $\mathrm{SpO}_{2}$ は正常值で ある98\%程度から下がる傾向を示す。体動刘策 については，各社信号処理上の改良を重䄈てい る.

装着上の注意としては，プローブのケーブルを 装着部位のそばにテープで固定すると改善され る、また，質量の大きなフィンガープローブより も，ディスポプローブの斿体動の影響を受けに $\langle$ (6).

\section{3. 熱 傷}

蛋白質は $42^{\circ} \mathrm{C}$ 超えると変質し，蛋白質から

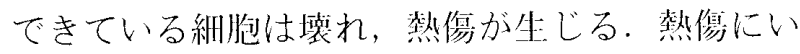

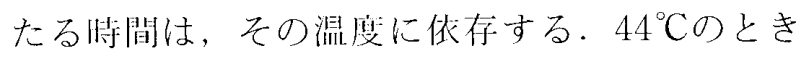
にI度のやけどに達する侍間は 3 時間 20 分であ り，韲度が $1^{\circ} \mathrm{C}$ 上杲すると熱㑺になる時間は，約 1/2になるとされている。

$\mathrm{SpO}_{2}$ プローブの発光素子の温度上昇は $2^{\circ} \mathrm{C}$ 程 度である。装着部の温度が $35^{\circ} \mathrm{C}$ とても, 装着

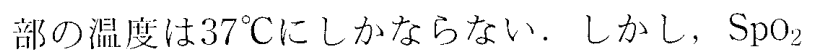
プローブによる熱傷がまれに発生する7)。たプ ローブ装着の冉迫だけで, 皮膚損傷が起こるとい う報告もある

生体の代謝による産熱は，血流により放熱され ている，压迫により血流が途絶えると，血液によ る放熱がなくなり局所的に温度が上昇する $\mathrm{SpO}_{2}$ プローブによる熱傷は, プローブ装着の压 迫と発光部の発熱の相乗效果であると考えられ る.

プローブ装着特には，以下の注意が必要であ る:

(1)辰時間連続して同一部位に装着しない

(2)テープで強く国定しない

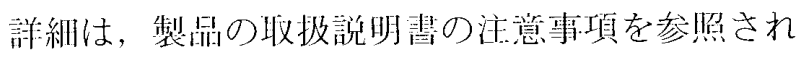
たい。

\section{臨床応用}

パルスオキシメータは, 休䣷中の安全確保を目 的として，1980年代の後半から急速に普及して
きた，現在では各方面の医療現場で日常使用され ている、ここでは，パルスオキシメータが盛り込 まれたガイドラインなどの例をいくつか紹介す る。

生体情報モ二タ 日本麻酔学会が1993年に定 めた“安全な麻酔のためのモニタ指釗”のなかに， 酸素化のチェックについて以下のように記載され ている：皮膚，粘膜，欰液の色などを看視するこ と、パルスオキシメータを装着すること。

同様の指針は，アメリカ，イギリス，オースト ラリア，オランダ，カナダその他数多諸外国で定 められている10).

新生児モ二タ 新生児集中治療領域では, $\mathrm{SpO}_{2}$ $92 \%$ 未満を低酸素林症としている。また未熟児 網膜症の予防のために，人工换気撩法中は98\% 以上にしない斿安全とされている11).

在宅酸素療法 慢性閉塞性肺疾患の治療法とし て，在宅酸素療法がある。この治療法の適用とし て “ $\mathrm{PaO}_{2} 55$ Torr 以下”あるいは“ $\mathrm{PaO}_{2} 60$ Torr

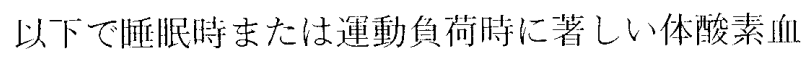
症をきたす”という基準が示されている。このと きの判定にパルスオキシメータを用いてもよいと されている。“ $\mathrm{PaO}_{2} 55$ Torr 以下”は $\mathrm{SpO}_{2} 88 \%$ 以下, “ $\mathrm{PaO}_{2} 60$ Torr 以下” は $\mathrm{SpO}_{2} 89 \%$ 以下と 一般に解釉される ${ }^{12)}$.

睡眠時無呼吸症候群 崡眠時無呼吸の診断は, 終夜睡眠ポリグラフ検查 (polysomnography: PSG) によって行う.PSGでは脳波, 眼球連動, 傎筋 電図 $(E M G)$ 鼻孔部之口の換気曲線，胸部之腹 部の呼吸運動曲線，心電図ならびに $\mathrm{SpO}_{2}$ を連続 的に記録することが必娎である。無呼吸は10秒 以上の換気停止であり，低呼吸とは換気曲線の振 幅が覚醒時呼吸の50\%以下で， $\mathrm{SpO}_{2}$ の $3 \%$ 以上 の低下か脳波上の覚醒反応を伴うものとされてい $3^{12)}$.

肺炎 日本呼吸器学会作成 “成人枋中肺炎診䝤 の基本的考元”にある肺炎重症度分類の判断基 準の一つに, $\mathrm{SpO}_{2} \leqq 90 \%$ という項目が盛り込ま れている13). 


\section{今後の動向}

パルスオキシメータに関する最近の研究とし て, 一酸化炭素中毒の早期判定のために, $\mathrm{COHb}$ を測定する試みが行われている。

$\mathrm{COHb}$ は前述のように, $\mathrm{SpO}_{2}$ 測定の阻害要因 となる、そこでパルスオキシメータの発光波長を 3 波長に拡張し非侵襲的に $\mathrm{COHb}$ 测定を行い, よい相関が得られたとある(14)。

パルスオキシメータの原理は，非侵襲，連続， リアルタイム測定という医療における基本的な要 求を満足するものである，この原理は酸素飽和度 測定にとどまらず，今後様々な応用が期待され る。

\section{文 献}

1）諏訪邦夫:パルスオキシメトリの歴史。パルスオキシ メ一夕, 中外医学社, 東京, 1989, pp71-77

2) Severinghaus JW, Astrup PB: History of Blood Gas Analysis, Little, Brown \& Co, Boston, 1987

3）青柳卓雄:パルスオキシメータの涎生とその理論, 麻 酷の教育と安全，克誠堂，東宗，1990，pp60-73

4) Barker SJ, Tremper KK: The Effect of Carbon
Monoxide Inhalation on Pulse Oximetry and Transcutaneous $\mathrm{PO}_{2}$, Anethesiology 1987; 66: 677-679

5）久保四勝ほか:パルスオキシメータによって経過覞察 することができた愛性アニリン中青の1例，日胸部疾 患会誌 1993; 31: 886-889

6）青柳卓雄ほか: パルスオキシメータの基碟，見在，未 来. Neonatal Care 2000; 13: 21-27

7）小林文人ほか:パルスオキシメータが信号をうまく拾 わない. LISA 2001; 840-842

8）木村千代子ほか：パルスオキシメータによる皮膚椇例 に関する 1 考察. ICU と CCU 1992；16: 1139-1141

9）山田幸生: 低温やけどについて。製品と宛全 1999; 72: $2-8$

10）日本㑣醉学会: 諸外国の麻酔のためのモ二タ一指釗, 灾全な麻醉のためのモニタ一指針，克誠堂，束京， 1995, pp13-25

11）和田紀久ほか:パルスオキシメーターどこまで頼れる か?. Neonatal Care 1999年春期增刊，メディ力出版， 大拻, 1999, pp48-55

12）循環器病の診断と治療に関するガイドライン。Jpn Circ J 2001; 65 (Supplement V): 1100-1106

13）河野茂ほか: 支柱肺炎のガイドラインをめぐって。呼 吸 2000; 19: 869-880

14）恢藤陽二ほか:パルスフォトメトリー法を朋いたヒト 一酸化炭素へモグロビン $(\mathrm{CO}-\mathrm{Hb})$ 测定。日救急因会誌 2001; 11: 527 